\title{
UDC 001.18
}

\section{P. PECHERANSKYI ${ }^{1 *}$}

${ }^{1 *}$ Kyiv National University of Culture and Arts (Kyiv, Ukraine), e-mail ipecheranskiy@ukr.net, ORCID 0000-0003-4722-2332

\section{Somatic Transformations in the Context of Antropotechnogynesis at the Modern Stage}

Purpose. The main purpose of the article is the analysis of the phenomenon and manifestations of the somatic transformations in the context of anthropo-technological evolution at the beginning of the XXI century. Theoretical basis. The author determines the understanding of the concept "somatic transformations" in the frames of anthropotechnogynesis is possible only on the base of integrative approach and combination of post-non-classical scientific paradigm methodology, theory of the technological development, ideas of trans-humanism, informative society concepts, and net technologies influence on the identity of the human being with robots in the sphere of bioethics and nanoethics, the ethics of new technologies and legal documents which are regulating the processes of technotransformation of the human being. Originality. The author has proved on the example of analysis of the somatic transformations own psychosomatics as he solves some important global in the context of anthropotechnogynesis that a person with help of technological enlargement of and branch problems, so he is trapped of alienation in the very crucial stage, loses the identity and crashes the corporeality in his self. Conclusions. As evidenced by the given analysis, at the modern stage the anthropotechnogynesis is followed by the large-scale quantitative and qualitative somatic transformations based on NBIC-convergence, as a result, a new anthropological subspecies - Homo technologicus appears. All these transformations are a regular stage of evolution, which confirms the thesis of the essential and functional connection of technology with the human body, which are in a relationship of "mutual provocation". In the base of the paradigmatic ontological and anthropological shift which has been on the modern stage, lies the idea of continuity of anthropotechnological co-evolution of the human body and its environment which projects itself in psychosomatic human structure, making a transformation program for better adaptation in technonanobeing. The convergence of human life and techno-existence is a platform for somatic transformations. They are divided into two main groups: intra-structural, substantial, related to techno-modification of the human body directly through biotechnology and genetic engineering, cyborgization, xenotransplantation, Hi-Hume connection with HiTech and others, and external-contextual, when under the influence of pancommunication and hybridization the environment is increasingly mentalized and somatized, and modern technologies are gradually transformed into the social body of man.

Keywords: anthropotechnogynesis; somatic transformations; Homo technologicus; NBIC-convergence; technological enlargement; somatization; cyborgization; techno-modification

\section{Introduction}

We live in the epoch of fundamental civilization movements and meet with "predatory technologies of the century", unrestrained development and total dominance of which actualizes and brings to a new level a long-standing problem - Me and my body. Among the challenges in the light of which human is increasingly rethinking himself through the prism of his own somatic transformations, first of all, I would like to single out anthropotechnological evolution, as a result of which a new anthropological subspecies is formed, better burdened by modern technologies Homo technologicus.

The appearance of this subspecies is spontaneous and is not a deviant divergence but is programmed by human nature itself, it appears as a natural stage of its evolution. As, in fact, technology and modern technological breakthrough, which does not occur out of thin air, but is the cumulative effect of previous technology. Analyzing the origin of the human and its difference from animal, anthropologists G. Plessner and A. Gehlen stressed on the non-biological way of positioning it in the world, which follows from the biological substrate: the first pointed to the 
"eccentricity" of man, due to which he "experiences the content of the environment, his own and others... also able to rule over his own flesh" (Plessner, 2004, p. 251), and the second writes about biological non-specialization, and hence about its inferiority and the emergence of man to action, the result of which is the artificial world of culture (language and technology), through which he is able to survive, "... all spiritual achievements of man can be understood from its ability to act" (Gehlen, 1988, p. 157).

Thus, technology is essentially and functionally related to the human body, which was one of the first emphasized by Marx: technology reveals the active attitude of man to nature, the direct process of production of his life, and at the same time his social living conditions and spiritual ideas, resulting from them (Wendling, 2009). This thesis is supported by the theory of "organoprojection", as evidenced by the thesis of E. Kapp (2018) that the body is the key to the peculiarities of human activity in all its spheres (p. 42), that in the process of human interaction and tools are mutually enriched, as well as the opinion of P. Florensky (1993) that "the study of organisms is the key to a technical invention, and vice versa, technical inventions can be seen as a reagent for our self-knowledge. Technology can and should provoke biology, as biology - technology" (p. 162).

In contrast to the theory of organoprojection, which states that technological tools are nothing more than transformed molds of human organs, M. McLuhan turns to the analysis of a qualitatively new level of technology, when any anthropomorphic analogies no longer work, and therefore he emphasizes that the most modern "high" technologies (telecommunications, electronics, space, transport, bio- and nanotechnology) are no longer projections and copies of the anatomy of the human body and organs, but their elongations and extension. As in the case of a car and an airplane, which become extensions of the musculoskeletal system, or clothing, home or city which expand the skin. In "Understanding Media: The Extensions of Man", the scholar also discusses a similar relationship between the wheel-foot and chair-butt pairs (McLuhan, 2013).

It is necessary to underline that the proposed approach by M. McLuhan reveals the importance of the idea of continuity of anthropotechnological co-evolution of the human body and its environment, including any technique. Using any new technological forms or invention change the human topology and its connection with the reality, any instruments in his hands direct not only outside, on objects of activity, but also inside the subject, changing the structure of his activity or generating new forms. Considering a new phase of technogenesis (complex selforganized systems) and fundamental human variability, his "eccentricity" and non-specialization is worth talking about the paradigmatic ontological and anthropological shift. It occurs at the present stage, associated with radical somatic transformations of man, when the idea of "selfexpansion", taking into account the achievements of science, becomes an integral part of anthropotechnological evolution. It reveals both the positive and negative aspects of the latter at the beginning of the third millennium.

\section{Purpose}

Given the above, the purpose of the article is to analyze the phenomenon and manifestations of somatic transformation in the context of anthropo-technological evolution at the beginning of the XXI century, which provides a consistent solution to the following problems: a) understanding the specific of technotransformation of the human being, especially its corporeality including the origin and logic of new technologies development; b) identification and consideration of types of somatic transformations that allow to outline the scale and consequences (positive and negative) of anthropotechnogenesis at the modern stage. 


\section{Statement of basic materials}

Trying to understand the specific and dynamic of somatic transformations of a human including the concept of "Technological enlargement" it is important to underline that this concept we understand as the idea of overcoming the natural inferiority of the person due to improvement of its functioning on the basis of NBIC-convergence that is Nano-Bio-Info-Cogno-Socio-AnthroPhilo-Geo-Eco-Urbo-Orbo-MacroMicro-Nano technologies. Moreover, the conditions for the possibility of using these technologies are implicit in human nature itself, including at the level of the body, which is an integral part of complex eco-, socio-technical and socio-cultural systems. We are talking about the actualization of a range of problems related to embryo-, morphogenesis, tissue differentiation, self-regulation of nanosystems with self-reproducing elements, their self-assembly "bottom-up" (bottom-up), self-regulation of the organism, genome, cell, evolutionary theory, population dynamics, proteomics, as well as with ideas and programs within the concept of connectionism - self-organization of networks of different types (neuro,- socio-, etc.), artificial life, etc. (Bensaude-Vincent \& Simon, 2019).

Representatives of nanoethics are right when they emphasize that in the discourse of human techno-transformation the main emphasis is on improving individual qualities (strength, speed, intelligence), and the issues of love, empathy, mutual support are virtually ignored (Est, Klaassen, Schuijff, \& Smits, 2008, p. 7). And this improvement is due to the strengthening of the relationship between human techno-evolution and the hybridization of reality or the environment in which it lives. The anthropological meaning of modern technological trends is to expand human corporality in space at a new level through local networks or the World Wide Web as a perceptual-afferent field (wireless sensor networks, etc.) and a remote efferent set of actuators of potential action. Due to the hybridization of reality through convergent technologies (RFID tags, codes, total computing, wireless sensor networks, RFID biochips, sensors, bioidentification, GPS, geotargeting, Augmented Reality, Internet of Things, etc.) fractal boundaries of bodies are delocalized in the temporal-spatial aspect, are "blurred" in the physical, physiological, existential and psychosensory dimensions (Norouzi et al., 2019). It is this delocalization in combination with the techno-socio-cultural blurring of the boundaries between "material" and digital existence that ensures the convergence of techno-life with human life, which serves as a platform for somatic transformations from the outside (pancommunication technology and hybrid reality) and inside (NBIC technology). As a result, the dualism of organic-inorganic, natural-artificial, and the body is increasingly technologized and the environment is mentalized and somatized.

Interesting in this regard is the term "intimate technology", which the Dutch philosopher Rinie van Est (2014) justifies. By "intimacy" he means that certain technology is the closest to a person, a carrier of very important and valuable information for him, as a result of which people cannot part with their gadgets for a second. The scientist identifies four types of technology: "technology in us" (RFID chips, electronic pills, cochlear implants, deep brain stimulation, artificial organs, etc.), "technology about us" (GPS, RFID readers, cameras, Google Street-view, DNA chips, heart rate and body temperature sensors, etc.), "technology between us" (social networks Facebook, Foursquare, Grinder, augmented reality (Google Glass)), "technology like us" (virtual worlds, chat-bots, e-coaching, etc.). All these technologies affect the expansion of somaticity: the former, whose action is directed inward, directly transform the body, while others do it indirectly, forming a favorable field of human technoevolution.

This is the specificity of anthropo-technological evolution at the modern stage, when human projects himself into the technological world, turning it into a means to realize their own needs. 
But in the same process, there is a reverse effect: the man-made environment projects itself into the psychosomatic structure of the human himself, setting for him a program of transformations in order to better adapt to the work of various technical devices. In essence, the technological system that is being formed today permeates human nature, modifying its essence. As J. Baudrillard (2000) noted, video, television, and the computer - these contact lenses and transparent prostheses - "form a whole with the body to the point of becoming a genetic part of it" (p. 86). We find a similar opinion in V. Rosin:

The Internet and mobile communications are gradually becoming another

socio-technical body of man (along with others - electricity, transport,

housing, clothing, etc.), enormously expanding its capabilities, on the

other hand, significantly transforming her psyche and partly her body.

(Rozin, 2016, p. 222)

At the modern stage, corporeality, realizing its own physiological and social functions in a networked society, is simultaneously transformed into transbody which is expressed at the intersection of living space, represented by the duality of the virtual and the real. Along with the simulation of reality, which transforms a person, there is a desire for self-identification, which leads to the acquisition of a new virtual body - "Internet corporeality". The latter appears as a result of the abolition of physical (physiological) corporeality by the entry of modern man into cyberspace. But isn't this way out a mistake that will have to be paid for by annihilating the body and corporeality of the real living space of the individual?

If we continue the author's opinion, it is not only about the Internet, mobile phones, smartphones, communicators, tablets and other gadgets, but also that according to the principles of automatic identification, a person's identification code must eventually be applied directly to his physical body. The idea of implanting microprocessor devices or "digital angels" in the body, which makes it possible to track the movement of the desired objects and determine their location, is becoming increasingly popular. This leads to the "de-privatization" of the person, the transformation of the subject and object into a commodity such as a sausage or mayonnaise in the supermarket. The European Group on Ethics in Science and New Technologies to the European Commission (2005) in 2005 prepared a thorough opinion "Ethical aspects of implants in the human body of information and communication technologies", which discussed, among other issues, the introduction of microchips into the human body related to their implementation of public and personal control.

Today we can confidently speak of the symbiosis of human and machine, which is manifested in the example of the objective process of cyborgization, which is developing today in several areas: solving problems caused by loss of organs or part of their functions (a famous example of prostheses athlete Oscar Pistorius); introduction of artificial implants or implantation of control microchips (from silicone "improvements" to artificial heart); supplementation of a healthy and physically complete body with electronic or mechanical devices (the most illustrative example is the use of an exoskeleton); tattoos and body piercing or bodybuilding work as examples of technological design, when transformations create the illusion of control over own body, because in 
fact, it is about submission to it when the whole life, routine, nutrition, communication are subordinated to the body and it becomes body reproduction machine. D. Haraway (1991) equates cyborgization to the deconstruction of man, and the cyborg to the postmodern chimera, which symbolizes the final combination of animal, human and machine. And for example Lauren M. Britton, in the dissertation, she presented the results of her own ethnographic research as an observer-participant. She together with the team of biohackers GrinderTech, which practices techno-modification of the body, emphasized the formation of cyborg identity as a "paradoxical integration" (Britton, 2017).

Thinking on the subject of robots, cyborgs, and androids, Polish anthropologist M. RadkowskaWalkowicz suggests the term "artificial man", emphasizing the ambitious plans of biotechnology and genetic engineering:

Today, in the era of advanced bionics, prosthetics, genetic engineering,

nano as well as the progress of robotics, the figure of an artificial person

acquires new meanings: there is, among others, a cyborg, a hybrid of a

living organism and a machine, and the possibilities of plastic surgery

cause man to believe that he can change his appearance against the will

of nature your judgment. (Radkowska-Walkowicz, 2008, p. 25)

Combining artificiality with sterility and cold objectivism, the author contrasts it with the emotionality and individualism of living people. On the example of the analysis of the artificial body of an android or a human-like robot, which is a denial of human somatics, M. RadkowskaWalkowicz (2008) shows the devastating effects of radical modification of the body in the context of cyborgization, when the body gradually loses its essential features experiencing and enjoying it (p. 309).

It would also like to note the role of Hi-Hume, given their connection with Hi-Tech within the concept of transhumanism, in the process of techno-transformation of human somatics. In essence, it goes about technologies leading evolution when in planned, the artificial mode is configured at the technological level of psychosomatics of a person. Manipulations take place in the following areas: the emergence of artificial intelligence systems and the further development of the human-computer interface; moving most of the activity into cyberspace and expanding the intellectual capabilities of man through sensory devices-implants; engineering of organs and tissues, creation of prostheses and artificial organs; purposeful intervention in human and animal genetics; practical suspension of aging processes; effective prevention and treatment of almost all diseases, etc. (Dubrovskiy, 2013, p. 230). And it is no coincidence that among this list F. Fukuyama brought genetic engineering to the first place, because, according to J. Habermas, the possibility of interfering in the human genome ("programming" of children, future generations, one of the key aspects of xenotransplantation, namely, human improvement using animal genes, the creation of man with the "addition" of animal material, etc.) is not only a somatic manipulation but a denial of the foundations of modern Western culture, turning man into a "lottery of genes". The incarnation of the human embryo by such manipulation and inference in the genome 
have negative consequences when a child with an altered set of genes becomes a "victim of gene manipulation" and his life is doomed, according to the German philosopher, to choose "between fatalism and resentment" (Habermas, 2010, p. 23).

\section{Originality}

The author has proved the thesis about the absurdity and deep tragedy of human living on the example of somatic transformations in the context of anthropo-technological evolution at the modern stage: trying to overcome the natural vulnerability and imperfection, man begins to act, invents and improves technologies by which he evolves and expands in his own psychosomatics. Instead of this expansion which leads to the loss of identity and freedom, to the destruction of the body in its own self. From one side, with the help of techno-evolution human solves the important global and branch problems, from another side, being surrounded by the artificial corporeality of modern social space, finds itself trapped in alienation at its most critical stage.

\section{Conclusions}

According to the analysis, anthropotechnogenesis is accompanied at the present stage by large-scale quantitative and qualitative somatic transformations caused by the main trends in the development of technocratic and information society at the beginning of the third millennium, resulting in a new anthropological subspecies - Homo technologicus. Its appearance is not spontaneous, but programmed by human nature itself, that is, it is a natural stage of its evolution, which confirms the thesis of the essential and functional connection of technology with the human body, which are in a relationship of "mutual provocation". If earlier this connection was determined by anthropomorphic analogies (theory of organ projection), today, given the new phase of technogenesis (complex self-organizing systems), it is established on the basis of "high" technologies and is denoted by the concept of "expansion".

Basically, the paradigmatic ontological and anthropological shift is the idea of the inseparability of the anthropo-technological coevolution of the human body and its environment. In the discourse of human techno-transformation the main emphasis is on improving individual qualities based on NBIC-convergence and strengthening the relationship between anthropotechnogenesis and hybridization of reality or the environment in which he lives: technogenic environment projects itself into the psychosomatic structure of man himself in order to better adapt to technonanolife. The use of any new technological form or invention changes the topology of man and his interaction with reality, any tool in his hands is directed not only outside but also inside the subject, changing the structure of its activities or generating new forms.

The anthropological meaning of modern technological trends is to expand human corporality in space through local networks and the World Wide Web, remote efferent set of actuators of potential action, as well as delocalization through convergent technologies of fractal boundaries of bodies, bringing together human life and technonanolife. This convergence is a platform for somatic transformations, which can be divided into two main groups: first, intra-structural, substantial, associated with techno-modification of the human body through biotechnology and genetic engineering, cyborgization, xenotransplantation, Hi-Hume in connection with Hi-Tech and others, and, secondly, external-contextual, when under the influence of pancommunication and hybridization the environment is increasingly mentalized and somatized, and modern technologies are gradually transformed into the social body of man, mainly embodied in the media - and 
Internet corporality. Along with the tangible benefits of such transcendence, the price to be paid is considerable: loss of identity and freedom, destruction of the corporeality in itself, "narcissistic anesthesia" and technodrug addiction, "de-privatization" and alienation.

\section{REFERENCES}

Baudrillard, J. (2000). La Transparence du Mal (L. Lyubarskaya \& Y. Markovskaya, Trans.). Moscow: Dobrosvet. (in Russian)

Bensaude-Vincent, B., \& Simon, J. (2019). Introduction. Nanotechnoscience: The End of the Beginning. Philosophia Scientae, 23-1, 5-17. DOI: https://doi.org/10.4000/philosophiascientiae.1723 (in English)

Britton, L. M. (2017). Manifesting the Cyborg via Techno-Body Modification: From Human Computer Interaction to Integration. Retrieved from https://surface.syr.edu/etd/757/ (in English)

Dubrovskiy, D. I. (Ed.). (2013). Global Future in 2045. Converging Technologies (NBICS) and Transhumanistic Evolution. Moscow: Izdatelstvo MBA. (in Russian)

Est, R. van. (2014). Intimate Technology: The Battle for Our Body and Behavior. The Hague: Rathenau Instituut. (in English)

Est, R. van, Klaassen, P., Schuijff, M., \& Smits, M. (2008). Future man - No future man: Connecting the technological, cultural and political dots of human enhancement. The Hague: Rathenau Institute. (in English)

Florensky, P. A. (1993). Organoproektsiya. In S. G. Semenova \& A. G. Gacheva (Eds.), Russkiy kosmizm: Antologiya filosofskoy mysli (pp. 149-162). Moscow: Pedagogika-Press. (in Russian)

Gehlen, A. (1988). On the taxonomy of anthropology (A. Filippov, Trans.). In Y. N. Popov (Ed.), Problema cheloveka $v$ zapadnoy filosofii (pp. 151-201). Moscow: Progress. (in Russian)

Habermas, J. (2010). Die Zukunft der menschlichen Natur. Suhrkamp Verlag. (in German)

Haraway, D. J. (1991). A Cyborg Manifesto: Science, Technology, and Socialist-Feminism in the Late Twentieth Century. In Simians, Cyborgs and Women: The Reinvention of Nature (pp. 149-181). London: Free Association Books. (in English)

Kapp, E. (2018). Elements of a Philosophy of Technology: On the Evolutionary History of Culture. Minneapolis: University of Minnesota Press. (in English)

McLuhan, M. (2013). Understanding media: The extensions of man. New York: Gingko Press. (in English)

Norouzi, N., Bruder, G., Belna, B., Mutter, S., Turgut, D., \& Welch, G. (2019). A Systematic Review of the Convergence of Augmented Reality, Intelligent Virtual Agents, and the Internet of Things. In F. AlTurjman (Ed.), Artificial Intelligence in IoT (pp. 1-24). Springer. DOI: https://doi.org/10.1007/978-3-03004110-6_1 (in English)

Plessner, H. (2004). Die Stufen des Organischen und der Mensch. Einleitung in die philosophische Anthropologie. Moscow: Rossiyskaya politicheskaya entsiklopediya. (in Russian)

Radkowska-Walkowicz, M. (2008). Od Golema do Terminatora. Wizerunki sztucznego czlowieka w kulturze. Warszawa: WaiP. (in Polish)

Rozin, V. M. (2016). Tekhnika i tekhnologiya: Ot kamennykh orudiy do Interneta i robotov. Yoshkar-Ola: Volga State University of Technology. (in Russian)

The European Group on Ethics in Science and New Technologies to the European Commission. (2005). Ethical aspects of ICT implants in the human body: Opinion No. 20. Retrieved from https://www.slideshare.net/ karlossvoboda16/ethical-aspect-of-ict-implants-in-human-body-opinion-20-en (in English)

Wendling, E. A. (2009). Karl Marx on Technology and Alienation. Palgrave Macmillan. (in English)

\section{LIST OF REFERENCE LINKS}

Бодрийяр Ж. Прозрачность зла / пер. с фр. Л. Любарской, Е. Марковской. Москва : Добросвет, 2000. 257 с. Bensaude-Vincent B., Simon J. Introduction. Nanotechnoscience: The End of the Beginning. Philosophia Scientae. 2019. Vol. 23-1. P. 5-17. DOI: https://doi.org/10.4000/philosophiascientiae.1723

Britton L. M. Manifesting the Cyborg via Techno-Body Modification: From Human Computer Interaction to Integration. 2017. URL: https://surface.syr.edu/etd/757/

Глобальное будущее 2045. Конвергентные технологии (НБИКС) и трансгуманистическая эволюиия / под ред. Д. И. Дубровского. Москва : Издательство МБА, 2013. 272 с. 
Van Est R. Intimate Technology: The Battle for Our Body and Behavior. The Hague : Rathenau Instituut, 2014. 86 p.

Van Est R., Klaassen P., Schuijff M., Smits M. Future man - No future man: Connecting the technological, cultural and political dots of human enhancement. The Hague : Rathenau Institute, 2008. 54 p.

Флоренский П. А. Органопроекция. Русский космизм: Антология философской мысли / сост. С. Г. Семенова, А. Г. Гачева. Москва : Педагогика-Пресс, 1993. С. 149-162.

Гелен А. О систематике антропологии / пер. А. Филиппова. Проблема человека в западной философии / под ред. Ю. Н. Попова. Москва : Прогресс, 1988. С. 151-201.

Habermas J. Die Zukunft der menschlichen Natur. Suhrkamp Verlag, 2010. 164 s.

Haraway D. J. A Cyborg Manifesto: Science, Technology, and Socialist-Feminism in the Late Twentieth Century. Simians, Cyborgs and Women: The Reinvention of Nature. London : Free Association Books, 1991. P. 149-181.

Kapp E. Elements of a Philosophy of Technology: On the Evolutionary History of Culture. Minneapolis : University of Minnesota Press, 2018. 336 p.

McLuhan M. Understanding media: The extensions of man. New York : Gingko Press, 2013. 402 p.

Norouzi N., Bruder G., Belna B., Mutter S., Turgut D., Welch G. A Systematic Review of the Convergence of Augmented Reality, Intelligent Virtual Agents, and the Internet of Things. Artificial Intelligence in IoT / ed. by F. Al-Turjman. Springer, 2019. P. 1-24. DOI: https://doi.org/10.1007/978-3-030-04110-6_1

Плеснер Х. Ступени органического и человек: Введение в философскую антропологию. Москва : РОССПЭН, 2004. $368 \mathrm{c}$.

Radkowska-Walkowicz M. Od Golema do Terminatora. Wizerunki sztucznego człowieka w kulturze. Warszawa : WaiP, 2008. $342 \mathrm{~s}$.

Розин В. М. Техника и технология: от каменных орудий до Интернета и роботов : монография. ЙошкарОла : Поволжский гос. технологический ун-т, 2016. 279 с.

Ethical aspects of ICT implants in the human body: Opinion No. 20 / The European Group on Ethics in Science and New Technologies to the European Commission. 2005. URL: https://www.slideshare.net/karlossvoboda16/ ethical-aspect-of-ict-implants-in-human-body-opinion-20-en

Wendling E. A. Karl Marx on Technology and Alienation. Palgrave Macmillan, 2009. 252 p.

\section{I. П. ПЕЧЕРАНСЬКИЙ ${ }^{1 *}$}

${ }^{1 *}$ Київський національний університет культури і мистецтв (Київ, Україна), ел. пошта ipecheranskiy@ukr.net, ORCID 0000-0003-4722-2332

\section{Соматичні трансформації в контексті антропотехногенезу на сучасному етапі}

Мета. Головною метою статті $є$ аналіз феномену та проявів соматичної трансформації в контексті антропотехнологічної еволюції на початку XXI століття. Теоретичний базис. Автор визначає, що розуміння концепту "соматичні трансформації" в рамках антропотехногенезу можливе лише на базі інтегративного підходу під час поєднання методології постнекласичної наукової парадигми, теорій технологічного розвитку людини, ідей трансгуманізму, концепцій інформаційного суспільства та впливу мережевих технологій на ідентичність людини з роботами у галузі біоетики та наноетики, етики нових технологій та нормативно-правовими документами, що регулюють процеси технотрансформації людини. Наукова новизна. Автором доведено на прикладі аналізу соматичних трансформацій в контексті антропотехногенезу, що людина за допомогою технологічного розширення власної психосоматики, як вирішує важливі глобальні та галузеві проблеми, так і опиняється в пастці відчуження в критичній іï стадії, втрачає ідентичність й руйнує тілесність в іï самості. Висновки. Як засвідчує проведений аналіз, антропотехногенез супроводжується на сучасному етапі масштабними кількісними та якісними соматичними трансформаціями на базі NBIC-конвергенції, внаслідок яких виникає новий антропологічний підвид - Homo technologicus. Ці трансформації є закономірним етапом еволюції, що підтверджує тезу про сутнісний та функціональний зв'язок технології з тілесністю людини, які перебувають у відношенні "взаємопровокування". В основі парадигмального онтологічного та антропологічного зсуву, який відбувся на сучасному етапі, лежить ідея нерозривності антропо-технологічної коеволюції людського тіла та його середовища, що проєктує себе у психосоматичну структуру людини, задаючи для неї програму трансформацій з метою кращої адаптації до технонанобуття. Зближення життесвіту людини та 
технонанобуття виступає платформою для соматичних трансформацій. Вони поділяються на дві основні групи: внутрішньо-структурні, субстанційні, пов’язані з техно-модифікацією безпосередньо тіла людини за допомогою біотехнологій та генної інженерії, кіборгізації, ксенотрансплантації, Нi-Нumе у зв’язку з Ні-Тесh та ін., та зовнішньо-контекстуальні, коли під впливом панкомунікації та гібридизації середовище все більше менталізується та соматизується, а сучасні технології поступово перетворюються на соціальне тіло людини.

Ключові слова: антропотехногенез; соматичні трансформації; Homo technologicus; NBIC-конвергенція; технологічне розширення; соматизація; кіборгізація; техно-модифікація

Received: 30.12 .2020

Accepted: 19.05.2021 